\title{
Thermolysin in human cultured keratinocyte isolation
}

\author{
Gragnani, A.*, Sobral, CS. and Ferreira, LM. \\ Division of Plastic Surgery, Surgery Department, Federal University of São Paulo - UNIFESP/EPM, \\ Rua Napoleão de Barros, 715, 4 andar, CEP 04024-002, Vila Clementino, São Paulo, SP, Brazil \\ *e-mail: alfredogf@ig.com.br \\ Received August 9, 2004 - Accepted November 10, 2005 - Distributed February 28, 2007
}

(With 4 figures)

\begin{abstract}
Background: When treating extensively burned patients using cultured epidermal sheets, the main problem is the time required for its production. Conventional keratinocyte isolation is usually done using Trypsin. We used a modification of the conventional isolation method in order to improve this process and increase the number of colonies from the isolated epidermal cell population. Purpose: To compare the action of trypsin and thermolysin in the keratinocyte isolation using newborn foreskin. Methods: This method used thermolysin as it selectively digests the dermo-epidermal junction. After dermis separation, the epidermis was digested by trypsin in order to obtain a cell suspension. Results: Compared to the conventional procedure, these experiments demonstrated that in the thermolysin group, the epidermis was easily detached from the dermis, there was no fibroblast contamination and there were a larger number of keratinocyte colonies which had a significant statistical difference. Conclusion: The number of colonies in the thermolysin group was significantly greater than in the trypsin group.
\end{abstract}

Keywords: keratinocyte, thermolysin, trypsin, colony forming efficiency.

\section{Termolisina no isolamento de queratinócitos cultivados humanos}

\begin{abstract}
Resumo
Introdução: No tratamento do paciente grande queimado, onde se usa lâminas de epiderme cultivadas, o principal problema é o tempo necessário para sua produção. O isolamento tradicional de queratinócitos utiliza normalmente tripsina. No presente estudo, foi utilizada uma modificação do método de isolamento tradicional, que poderia produzir uma maior pureza e um maior número de colônias formadas a partir da população de células epidérmicas isoladas. Objetivo: Comparar a ação da tripsina e da termolisina no isolamento de queratinócitos usando pele de prepúcio de récem-nascidos. Métodos: Essa metodologia utilizou a termolisina, que realiza a separação seletiva entre a epiderme e a derme. Após essa separação, a epiderme foi submetida à ação da tripsina para a obtenção da suspensão celular. Resultados: Comparado ao método convencional, os experimentos mostraram que no grupo da termolisina mostrou facilidade para a separação entre a epiderme e derme, não houve contaminação por fibroblastos e produziu um maior número de colônias formadas, com diferença estatística significante. Conclusão: O número de colônias no grupo termolisina foi significantemente maior que no grupo tripsina.
\end{abstract}

Palavras-chave: queratinócitos, termolisina, tripsina, formação de colônias.

\section{Introduction}

In the last few decades, there have been major developments in skin cell culture (Prunieras et al., 1976) making its experimental (Rheinwald and Green, 1977; Rheinwald, 1980; Pasch et al., 1999) and clinical use (Gallico et al., 1984; Cuono et al., 1987; Boyce et al., 1993; Tompkins and Burke, 1996) possible. The disadvantages of this technique are still related to its high costs and time required for keratinocyte culture (Morgan and Yarmush, 1997).

Proliferative keratinocytes are small epithelial cells, located at the top of the epidermic basal membrane char- acterized by a low division rate (Green, 1991). When enzimatically treated for serial culture, many of these cells will not be able to develop colonies, due to their state of differentiation. Only 3 to $4 \%$ of the keratinocytes can form colonies, even in excellent culture conditions. The formation and confluence of the colonies are directly related to the keratinocyte layer produced, which will be used as a graft (Leigh et al., 1994).

Nowadays, the most widely used method involves digesting the skin with trypsin (Rheinwald and Green, 1975). As the dermis is still present during this proce- 
dure, some fibroblasts may be isolated. Although keratinocytes constitute almost $90 \%$ of the dissociated cells, the fibroblast growth potential in the culture makes then undesirable contaminants (Karasek, 1983).

Various alternative methods have been described in order to separate keratinocytes from fibroblasts. The most effective of these methods seems to be the enzymatic separation using proteolytic enzymes (Karasek, 1983; Walzer et al., 1989).

Various enzymatical methods for dermal-epidermal separation have been described (Tompkins and Burke, 1996; Morgan and Yarmush, 1997). Trypsin separates supra basal hemidesmossomes often leading basal layer cells still attached to dermal pieces.

In 1977 a new enzyme, produced by Bacilum termoliticum was described as an alternative method for keratinocyte isolation. It seemed to be more effective than the other enzyme protocols (Henrikson, 1977; Feder and Schuck, 1977). Thermolysin selectively separates desmossomes (Green, 1991; Leigh et al., 1994). Probably due to this characteristic, this enzyme is able to separate the skin at the basal membrane zone level. Some authors have proved that thermolysin is able to produce an efficient dermal-epidermal separation (Walzer et al., 1989).

Some experiments using adult patient skin biopsies comparing thermolysin and different methods were done previously. Hyperproliferative skin biopsies have also been used, as well as in animal models (Germain et al., 1993; Glade et al., 1996; Rijnkels et al., 2001).

The literature suggests that thermolysin could be used in keratinocyte isolation successfully. This data can be questioned due to not many experiments having been done and the age of the patients studied differs so much from the control group.

In this experiment, the keratinocyte isolation method using trypsin and the treatment group using thermolysin followed by trypsin were used. The colony formation number from a well established age group of patients was also used.

The differences between skin biopsies processed using trypsin or thermolysin followed by trypsin were investigated and this will be demonstrated by a colony forming efficiency number.

\section{Methods}

\subsection{Cultured keratinocyte}

The cultured keratinocyte protocol was developed by Rheinwald and Green (1975), which was used here with some modifications introduced in our laboratory by Gragnani et al. (2002).

The protocol uses a feeder layer constituted by 3T3-J2 fibroblasts and they were seeded in $175 \mathrm{~cm}^{2}$ flasks with a density of 500,000 cells per flask using 40 $\mathrm{mL}$ of culture medium specific for 3T3-J2 fibroblasts and exchanged once every two days.
The cell proliferation kept its genetic characteristic and was used as a feeder layer until the keratinocyte isolation occurred. The day before isolation, 3T3-J2 cells were transferred to $75 \mathrm{~cm}^{2}$ flasks with a cell density of 2,000,000 cells per flask with $15 \mathrm{~mL}$ culture medium. Each feeder layer flask was prepared for each skin biopsy.

On the morning of the isolation procedure, the 3T3-J2 cells should have reached 50\% confluency and then were treated with $15 \mu \mathrm{g} / \mathrm{mL}$ mitomycin $\mathrm{C}$ added to the medium for 2 hours, which limits proliferation of fibroblasts. After 2 hours, the mitomycin was removed and the flasks were washed three times with Dulbecco modified Eagle medium (DMEM). Afterwards keratinocyte culture medium free of epidermic growth factor was added, at least 2 hours before keratinocyte isolation.

The isolation procedure began on the morning when patients were submitted to postectomy. $1 \mathrm{~cm}^{2}$ of foreskin was obtained and was sent to the laboratory in $50 \mathrm{~mL}$ Falcon tubes with $30 \mathrm{~mL}$ keratinocyte culture media free of epidermal growth factor. The fragments were processed for 6 hours after obtaining them.

The fragments were placed in $100 \mathrm{~mm}$ tissue plates with $1 \mathrm{~mL}$ of Phosphate buffered saline (PBS). The foreskin was dissected to take off all the connective tissue and make the cellular enzymatic separation possible. Later, the biopsy was placed in a $50 \mathrm{~mL}$ Falcon tube with $35 \mathrm{~mL}$ PBS solution and the tube was vigorously agitated for 45 seconds. This procedure was repeated 8 times with different PBS tubes in order to remove all contaminants.

Each fragment was divided into two. One piece was treated with trypsin (Green, 1991) and the other one was treated with thermolysin (Walzer et al., 1989). Each fragment was placed in a culture dish with the respective enzyme, trypsin or thermolysin.

The first sample was placed in a $60 \mathrm{~mm}$ tissue cultive plate with $3 \mathrm{~mL}$ of trypsin and was sectioned into very small pieces (the size was approximately $0.5 \mathrm{~mm}^{3}$ ) for almost 15 minutes. These small pieces were put into an agitator tube with $6 \mathrm{~mL}$ of versene and another $3 \mathrm{~mL}$ of trypsin resulting in a total volume of $12 \mathrm{~mL}$. The use of trypsin (1-300) $0.1 \%$, Versene or EDTA solution $5 \mathrm{~mm}$ and mechanical power helped the dermal-epidermal separation of the skin.

After 30 minutes, the supernatant of the agitator flask was taken. This solution with the keratinocytes was centrifuged (6000 rpm for 5 minutes) and re-suspended with $3 \mathrm{~mL}$ of keratinocyte medium. This medium came from the 3T3 J2 flask and was then seeded.

$6 \mathrm{~mL}$ of versene and $6 \mathrm{~mL}$ of trypsin were added again to the agitator flask. By doing this the skin pieces, which were not enzymatically separated, would be treated and keratinocyte isolation occured. After seeding a second time, the flask was kept in a wet $5 \% \mathrm{CO}_{2}$ and $37{ }^{\circ} \mathrm{C}$ incubator and the medium was exchanged every two days. 
The second part of the fragment was cut into fragments smaller than $5 \mathrm{~mm}^{2}$ and incubated in a $500 \mu \mathrm{g} / \mathrm{mL}$ thermolysin solution and HEPES buffer for 2 hours at $37{ }^{\circ} \mathrm{C}$. Afterwards, the dermal-epidermal separation was done with very delicate instruments. The epidermis was than processed using the same isolation procedure as described above.

After 12 days, both flasks were fixed with formol $10 \%$, colored with Rhodamine B and microscopically counted.

After being treated with enzymes and before the dermal-epidermal separation using delicate instruments, a sample of each enzyme treatment was taken for a histological study to evaluate the skin structure.

\subsection{Statistics}

In order to verify the colony forming efficiency number of two previously defined groups, we used the nonparametric test for two non independent samples of Wilcoxon.

This test was used because the skin used in this experiment is the same for both methods in each experiment, only divided into two segments.

The rejection level for a hypothesis was fixed in smaller amounts or equal amounts to $0.05(5 \%)$.

\section{Results}

These experiments were done on newborn human skin specimens. Two keratinocyte isolation methods were compared, using as control the traditional method described by Rheinwald and Green (1975).

Skin from the same donor was used in each experiment, comparing the trypsin and thermolysin group. The first method consisted of treating the skin with 2 subsequent trypsin digestions. The second method consisted of skin incubation with thermolysin for 2 hours at $37^{\circ} \mathrm{C}$. Thus, an easy separation at the dermal-epidermal junction was obtained; the whole epidermis with a complete basal cell layer was then disaggregated with 2 sequential trypsin digestions of 30 minutes each.

In this experiment, the dermal-epidermal separation occurred in the thermolysin group and did not occur in the trypsin group. That data was confirmed using a histological evaluation. Thermolysin caused detaching in the basal membrane zone, causing selective hemidesmossomes digestion. Trypsin, on the other hand, made a random segmentation and digestion of keratinocytes (Figures 1 and 2).

In the thermolysin group, there was no contamination with fibroblasts. However, this occurred in the trypsin group.

The colony forming efficiency was compared in both groups. Both techniques were able to produce viable colonies. The number of colonies in the thermolysin group was significantly greater and it could be seen in the average of colony numbers as well as in the rhodamine staining (Figure 3, 4).

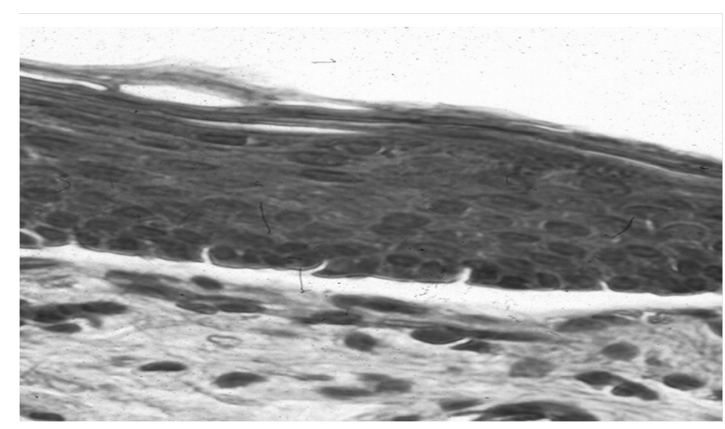

Figure 1. Histological aspect of fragment treated by thermolysin, HE (400x).

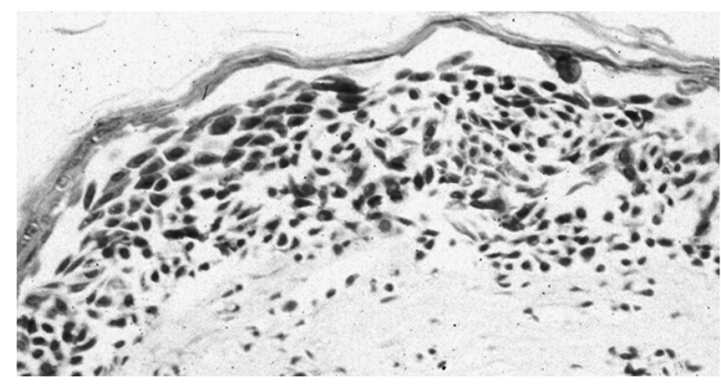

Figure 2. Histological aspect of fragment treated by trypsin, HE (200x).

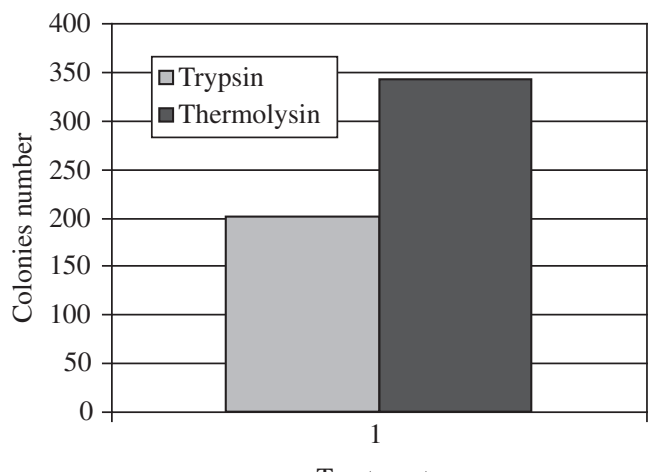

Treatment

Figure 3. Average of keratinocyte colonies number and treatment by trypsin or thermolysin.

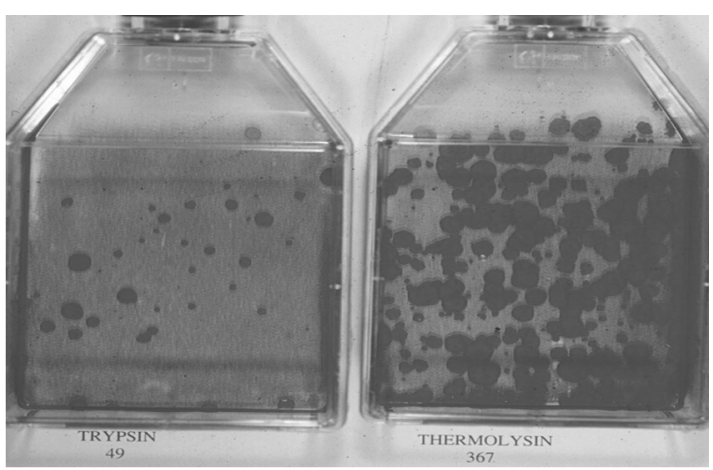

Figure 4. Rhodamine staining of the thermolysin and trypsin groups. 


\section{Discussion}

The use of the same skin donor was crucial in this experiment as the keratinocyte colony number to be genetically controlled has been proven (Popova et al., 2002).

Despite the apparent simplicity of counting colonies, many authors have used this method. It is simple, but reliable. For example, it can be used to examine the distribution of clonogenic keratinocytes within the hair follicle (Rochat et al., 1994), to evaluate the effect of radiation on keratinocytes (Cummins et al., 1999) and even affirm the number of keratinocyte colonies which represent a new genetically definable quantitative trait (Popova et al., 2002)

In studies using thermolysin to obtain keratinocyte isolation, the thermolysin treatment produced a greater number of colonies, leading to an earlier confluence. This data suggested a consequent small cultivation time, as well as low cost (Germain et al., 1993).

Other articles demonstrated an outright action of thermolysin in keratinocyte extraction from the basal membrane zone. Due to the specific action of thermolysin in the basal membrane zone, it becomes exposed and makes the following action of trypsin possible causing a more effective keratinocyte extraction (Walzer et al., 1989; Germain et al., 1993; Glade et al., 1996).

As one of the problems involving skin culture is still the cost, alternative experiments are useful to develop most effective and less expensive techniques (Gragnani et al., 2002).

More recently, other studies have been published using thermolysin. Its action to isolate complete pilosebaceous units were obtained by thermolysin digestion and inserted in this skin equivalent (Michel et al., 1999).

In this experiment, the skin fragments treated with thermolysin were easily detached from the dermis, which did not occur in the trypsin treated group. Due to this separation, there was no contamination with fibroblasts in the thermolysin group.

Histological evaluation showed a separation at the level of the basal membrane zone, when the samples were treated with thermolysin. The samples treated with trypsin presented a chaotic separation, without a clivage plan.

The technique necessary to produce dermo-epidermic separation depends on the enzymatic concentration, temperature and thickness of skin samples. In the thermolysin group, the dermal-epidermal separation occurred before using trypsin, and the epidermis became more sensitive to the trypsin action, mainly the basal keratinocytes. Because of this, it is possible to extract a greater number of keratinocytes in the proliferation phase, and consequently produce a greater number of colonies.

Due to the specific thermolysin action on hemidesmossomes, the basal membrane zone became exposed. It makes more efficient the keratinocytes isolation by trypsin.
Other experiments should be done comparing different aged patients, using thermoliysin, as well as using different times of exposure of the basal membrane zone to trypsin. Other experiments could evaluate other cellular passages, which was not possible in this experiment because the colonies were fixed with formalin.

Very recently an improved method to isolate epidermal cells and to enrich stem cell populations was published. It involved trypsin-EDTA only, thermolysin, or dispase protocols. Moreover, the total number of colonyforming cells per square was used to analyse each group (Park et al., 2004).

The use of flow cytometry with the optimization of protocols for cell sorting also compared thermolysin and trypsin, and their ability to preserve clonogenic potential of cells (Seegers et al., 2000). However, there is no conclusion concerning which enzyme should be used, and it seems to be related to the type of marker used to study Keratinocytes (Van Rossum et al., 2002; Franssen et al., 2003).

More research about keratinocyte isolation and characterization should be performed in order to provide an extensive growth potential and consequently clinical improvement in clinical use of cultured keratinocytes, but the efficient clinical use of this technique is now reliable and makes the protocol in less time.

\section{References}

BOYCE, ST., GREENHALGH, DG., KAGAN, RJ., HOUSINGER T., SORRELL, JM., CHILDRESS, CP., RIEMAN, M. and WARDEN, GD., 1993. Skin Anatomy and antigen expression after burn wound closure with composite grafts of cultured skin cells and biopolymers. Plast Reconstr Surg, vol. 91, no. 4, p. 632-641.

CUMMINS, RJ., MOTHERSILL, C., SEYMOUR, CB., JOHNS, H. and JOINER, MC., 1999. The effect of microcolony size, at time of irradiation, on colony forming ability. Int $\mathrm{J}$ Radiat Biol. 1999 Feb, vol. 75, no. 2, p. 225-32.

CUONO, CB., LANGDON, R., BIRCHALL, N., BARTTELBORT, S. and MCGUIRE J., 1987. Composite autologous - allogenic skin replacement: Development and clinical application. Plast Reconstr Surg, vol. 80, no. 4, p. 626-637.

FEDER, T. and SCHUCK, JM., 1977. Studies on the Bacillus subtilis neutral-protease and substrates. Biochem, vol. 9, no. 14, p. 2784-91.

FRANSSEN, ME., SMIT, JV., VAN ERP, PE. and VAN DE KERKHOF, PC., 2003. A multiparameter flow cytometric analysis of the effect of bexarotene on the epidermis of the psoriatic lesion. Br J Dermatol. 2003 Sep, vol. 149, no. 3, p. 506-12.

GALLICO, GG., O'CONNOR, NE., COMPTON, CC., KEHIND O. and GREEN, H., 1984. Permanent coverage of large burn wounds with autologous cultured human epitelium. New Engl J of Med, vol. 311, no. 7, p. 448-451.

GERMAIN, L, HOUABHIA, M, GUINARD, R, CARRIER, L, BOUVARD, V. and AUGER, AF., 1993. Improvement of human keratinocyte isolation and culture using thermolysin. Burns 1993, vol. 19, no. 2, p. 99-104. 
GLADE, CP., SEEGERS, BA., MEULEN, EF., VAN HOOIJDONK, CA., VAN ERP, PE. and VAN DE KERKHOF, PC., 1996. Multiparameter flow cytometric characterization of epidermal cell suspensions prepared from normal and hiperproliferative human skin using an optimized thermolysin-tripsin protocol. Arch of Dermatol Res, vol. 288, no. 4, p. 203-10.

GRAGNANI, A., MORGAN, JR. and FERREIRA, LM., 2002. Differentiation and barrier formation of a cultured composite skin graft. J Burn Care Rehab, vol. 23, no. 2, p. 126-31.

GREEN, H., 1991. Cultured cells for the treatment of disease: The successful growth of human skin cells in culture has made it possible to restore epidermis after severe burns and other forms of damage. Scientific American, p. 96-102.

HENRIKSON, RL., 1977. Aplications of thermolysin in protein structural analysis. Method Enzimol, vol. 47, no. 2, p. 175-89.

KARASEK, MA., 1983. Cell culture of human skin epidermal cells. In: Goldsmith LA. (ed.) Biochemistry and physiology of the skin. OUP, Oxford, NY, p. 230-40.

LEIGH, IM., LANE, EB. and WATT, FM., 1994. The Keratinocyte Handbook 1st ed. Cambridge, University Press, p. 566.

MiCHEL, M., L'HeUREUX, N., POUliot, R., XU, W., AUGER, FA. and GERMAIN, L., 1999. Characterization of a new tissue-engineered human skin equivalent with hair. In Vitro Cell Dev Biol Anim., 1999 Jun, vol. 35, no. 6, p. 318-26.

MORGAN, JR. and YARMUSH, ML., 1997. Bioengineered skin substitutes. Science \& Medicine, vol. 4, no. 4, p. 6-15.

PARK, HS., KANG, HJ., KIM, CH., KIM, CH., HAN, ES., HAN, K., KIM, TH., GIN, YJ. and SON, YS., 2004. Application of physical force is essential to enrich for epidermal stem cells in primary human keratinocyte isolation. Tissue Eng., 2004 Mar-Apr, vol. 10, no. 3-4, p. 343-51.

PASCH, J., SCHIEFER, A., HESCHEL, I. and RAU, G., 1999. Cryopreservation of keratinocytes in a monolayer. Cryobiology, vol. 39 , no. 2, p. 158-168.

POPOVA, NV., TRYSON, KA., WU, KQ. and MORRIS, RJ., 2002. Evidence that the keratinocyte colony number is genetically controlled. Exp Dermatol., 2002 Dec, vol. 11, no. 6, p. 503-8.
PRUNIERAS, M., DELESClUSE, C. and REGNIER, M., 1976. The culture of skin. A review of theories and experimental methods. J Invest Dermatol, vol. 67, no. 1, p. 58-65.

RHEINWALD, JG. and GREEN, H., 1975. Serial cultivation of strains of human epidermal keratinocytes: The formation of the keratinizingcolonies from single cells. Cell, vol. 6, no. 3, p. 331-43.

RHEINWALD, JG. and GREEN, H., 1977. Epidermal growth factor and the multiplication of cultured human epidermal keratinocytes. Nature, vol. 265, no. 5593, p. 421-4.

RHEINWALD, JG., 1980. Serial cultivation of normal human epidermal keratinocites. Methods in Cell Biology, 21a, p. 229-254.

RIJNKELS, JM., WHITELEY, LO. and BEIJERSBERGEN VAN HENEGOUWEN, GM., 2001. Time and dose-related ultraviolet $\mathrm{B}$ damage in viable pig skin explants held in a newly developed organ culture system. Photochem Photobiol, vol. 73, no. 5, p. 499-504.

ROCHAT, A., KOBAYASHI, K. and BARRANDON, Y., 1994. Location of stem cells of human hair follicles by clonal analysis. Cell. 1994 Mar 25, vol. 76, no. 6, p. 1063-73.

SEEGERS, BA., GLADE, CP., VAN HOOIJDONK, CA., VAN ERP, PE., DE JONGH, GJ. and VAN DE KERKHOF, PC., 2000. Flow-cytometric characterization of normal versus psoriatic epidermis using improved cell separation methodology. Exp Dermatol., 2000 Aug, vol. 9, no. 4, p. 266-70

TOMPKINS, RG. and BURKE, JF., 1996. Alternative wound coverings. In: Herndon DN. Total Burn Care WB Saunders Company Ltda, p. 164-172.

VAN ROSSUM, MM, SCHALKWIJK, J, VAN DE KERKHOF, PC. and VAN ERP, PE., 2002. Immunofluorescent surface labelling, flow sorting and culturing of putative epidermal stem cells derived from small skin punch biopsies. J Immunol Methods., 2002 Sep 15, vol. 267, no. 2, p. 109-17.

WALZER, C., BENATHAN, M. and FRENK, E., 1989. Thermolysin treatment a new method for dermo-epidermal separation. J Invest Dermatol, vol. 92, no. 1, p. 78-81. 